\title{
STUDENTS' MOTIVATIONS IN ENGLISH LANGUAGE LEARNING OF EFL CLASSROOM: A CASE STUDY OF ENGLISH DEPARTMENT STUDENTS OF ACADEMIC YEAR 2018/2019 IKIP SILIWANGI BANDUNG
}

\author{
Hendra Husnussalam¹, Sudiyono², Silpia Rahayu ${ }^{3}$ \\ ${ }^{1}$ IKIP Siliwangi \\ ${ }^{2}$ IKIP Siliwangi \\ ${ }^{3}$ IKIP Siliwangi \\ ${ }^{1}$ metalboyz79@yahoo.com, ${ }^{2}$ sudiyonostkipslw@ gmail.com, ${ }^{3}$ silviarahayu41@yahoo.com
}

\begin{abstract}
Some psychologists and educationalists have explained various models related to students' motivation in learning English language. One of them is proposed by (Gardner, 1988) who explained about the socio-educational model. This study reports data from the interview conducted to the English Department students of IKIP Siliwangi of Academic Year 2018/2019 about their motivation in English language learning. In this research, there are three students of English Department as the participants. In addition to the researcher, the instrument of this study is Interview which is applied to the three students based on their language ability levels; namely, high, moderate and low. This study belongs to Qualitative research because there is no statistical data presented. Instead, the data were collected by using structured interview and then, they were transcribed, categorized and interpreted. The findings revealed that there are three factors for the students that makes the students of English Department becomes more motivated in English language learning; namely, the teacher himself, the teaching strategies and games.
\end{abstract}

Keywords: Students' Perception, English Language, Traditional Classroom

\section{INTRODUCTION}

English language is always used as an international communication tool among countries in the world. Language has central role on intellectual development, social, and emotional students to supported success student and learn all of lessons, Parmawati (2018). Many fields use English as a daily communication tool, such education, business, politics, etc. No wonder, English is important to master because in the globalization era, there are always competitions among people. If we do not master English, we will get many loses in this modern life. In other words, mastering English is none but important for us in order to be able to compete with other people around the world.

Brown (2001) as cited in (Slattery, M., \& Willis, 2001)stated that English language learning aims to enable the students to be able to participate in such kind of enjoyable conversation, question and answer session. And according to Permendiknas (2006) as cited in (Syarifuddin, 2017) the students are expected to involve and understand short conversation, interpersonally or transactionally, in interacting with other people.

English language learning, however, is not an easy thing to do. Students often have 
difficulties in learning it. This is caused by several factors which hinder them to feel enjoyable when they learn English. That is why, it is important to create positive atmosphere in English language learning. However, it is not the only the teacher to create such kind of atmosphere. Together with the students and available sources, we have to be able to create more enjoyable English language learning so the students do not feel anxious (Tanveer, 2007). This is what this study does, related to how we can create such kind of English language positive environment. So, the questions for this study are: (1) what kind of teachers do you like? (2) what kind of teaching strategies are more interesting and effective in order to create more enjoyable English language learning?

Some psychologists and educationalists have explained various models related to students' motivation in learning English language. One of them is proposed by (Gardner, 2010)who explained about the socio-educational model. Through this model, there are two types of motivation, integrative and instrumental motivation. The first one refers to the students' desire to learn the target language in order to be able to communicate and integrate with other people of the target society. And the latter is the more purposeful reasons for learning foreign language; such as, getting jobs, high salary, and communicating language for the sake of daily life routines such as, shopping or travelling.

However, Gardner's model develops new component, such as cognitive-based one, which explains that in spite of individual's motivational characteristics, other cognitive psychological factors also plays important role for a person in order to improve his or her ability in learning language.

(Gardner, 2007) stated that, in language learning activities, the most dominant component is motivation. To assess this such motivation, we can use Motivational Intensity (MI), Desire to Learn Language (Desire), and Attitudes towards language learning (A). That is why; there are variables influencing motivation; attitudes, integrative, and instrumental one.

Talking about attitudes towards language learning atmosphere means that we are talking about positive or negative ones. Those with positive attitudes, instead of negative ones, always get good results in language learning. In other words, to master language easily and practically, the first thing we have to consider is the attitude because, according to Gardner, it is the major component in socio-educational model.

Integrative motivation is the students' open attitude to identify his or herself among the second language society members (Gardner, 2007). Those with integrative motivation always feel more interested and comfortable in learning the foreign language. In other words, they always show positive attitudes towards any situation of language learning. When they have that attitudes, they extend their effort to master or understand the second/foreign language.

Instrumental motivation is the students' desire in learning the second/foreign language. This motivation is mainly influenced when they want to complete interpersonal or even non-interpersonal ends, such as getting better jobs, high salary, and even continuing study in English-speaking countries.

\section{METHOD}

\section{Design}

This study employs qualitative research, especially it is related to phenomenological 
interview (LeCompte \& Preissle, 1993) as cited in (Gehart, D. R., Ratliff, D. A., \& Lyle, 2001). The researcher focused the attention on the students' beliefs, experiences and feelings so to understand their perspective of foreign/second language motivation. Through qualitative approach, the researcher is able to capture the students' own voices. Besides, the researcher is able to investigate the students' words and beliefs so to comprehend the phenomenon of language learning and answer the formulation of problem.

\section{Setting}

This research was conducted in IKIP Siliwangi Bandung, especially to the students of Academic Year 2018/2019 of English Education Study Program. There are three classes for the students of Academic Year 2018/2019. The researcher decided to choose one class only. It is Class A1.

\section{Sample}

As having been previously mentioned that the class to be the participants is class A1 of Academic Year 2018/2019. There are 40 students in this class. As for the sample, this research involves three students of the three level of English language ability; namely, high, moderate and low. They are purposively selected by the researcher in order to be able to answer the two questions. These students major in undergraduate level English Education Department of IKIP Siliwangi Bandung. They, as the sample, enable the researcher to get many potential information in related to the two study questions to be answered. More practically, the selection of these students is based on their academic level and Grade Point Average (GPA).

\section{Data Collection}

To collect the data, the researcher used structured interview. The selection of this method aims at creating more relaxed climate for the participants in expressing their opinions, attitudes, and paradigm through oral activities. The next reason behind the selection of this method is to motivate the students in exploring descriptively their answers related to the issue being discussed.

The interview itself is based on a guide piloted previously before conducting the research. The questions of interview are related to a number of questions, how to start the interview and how to end it in a systematic manner. The questions of this interview are mostly based on the theoretical framework of Gardner's model (2005). Shortly, this interview guide is based on the research questions.

In addition to note-taking, the researcher recorded the data through a digital recorder also. So, there are three interviews with three individual students conducted in the college of the researcher. The individual interview itself lasted about 30 minutes each.

\section{Data Analysis}

The data analysis of this study was conducted through two phases. The first one is transcribing the data into categorization in the form of texts and paragraphs. The second one is analysis of the data based on the recorded data from the interviews. Based on this analysis, it is revealed that the samples explain their strong needs to study English to get better future or career.

\section{RESULTS AND DISCUSSION}

\section{Results}

To make it more readable and understandable, then, the researcher divided the findings from the three students as the sample into Findings 1 (it means this finding is from the Student 1), Findings 2 (it means this finding is from the Student 2), and Findings 3 (it 
means this finding is from the Student 3). Once again, these three students are given two research questions: what kind of teacher do you like? And what kind of teaching strategies are more interesting and effective in order to create more enjoyable English language learning?

\section{Findings 1}

Based on the data analysis, it is revealed that the Student 1, 2, and 3 gave the following answers to the first research question: what kind of teacher do you like?

Student 1: menurut saya, guru itu harus memiliki selera humor yang menyenangkan jangan terlalu serius (In my opinion, the teacher must have more enjoyable sense of humor, don't get too serious).

Student 2: agar siswa lebih terlibat aktif dalam pembelajaran, sebaiknya guru itu harus menyenangkan, murah senyum dan bisa memahami setiap karakter siswanya (in order for the students to get more involved, the teacher has to be more enjoyable, always smile, and can understand every character of his or her students).

Student 3: saya mah tidak begitu suka kalau guru mengajarnya dengan monoton, sungguh sangat membosankan yaa, ke siswanya juga jadi kurang deh motivasinya (well...I don't like a teacher who teaches in monotone ways, it's very boring you know, so the students are less motivated)

\section{Findings 2}

Based on the second research questions, what kind of teaching strategies are more interesting and effective in order to create more enjoyable English language learning? it is revealed that the Student 1, 2 and 3 gave the following answers:

Student 1: "Saya kira akan lebih menyenangkan kalau guru dapat menciptakan iklim yang kondusif di mana siswa bisa terlibat lebih aktif dalam pembelajaran, jadi jangan guru terus yang aktif' (Well...I think the activity of teaching and learning will be more interesting if the teacher is able to create conducive classroom climate, so the students will be more active too in the class, not only the teacher who is more active).

Student 2: Saya pikir dalam hal - hal tertentu, saya lebih menyukai games karena secara tidak langsung alam bawah sadar kita sedang berinteraksi dengan alam sekitar dalam menyerap materi pelajaran (in my opinion, in certain case, I prefer games as the way to deliver the material because our consciousness is indirectly interacting with the nature around to absorb the teaching material).

Student 3: Kalau menurut saya sih, apa ya....guru itu harus terbuka terhadap berbagai pertanyaan dari siswa agar terjadi diskusi yang lebih interaktif lagi, karena para siswa juga belum tentu bisa menguasai materi pelajaran dalam sekali waktu atau tanpa diskusi (In my opinion, the teacher has to be more open-minded in answering students' question in more interactive discussion, because not all students can directly understand the materials without discussion).

\section{Discussion}

Based on Findings 1, related to the question: what kind of teacher do you like? then, it is revealed that the students prefer the teacher who has sense of humor, more enjoyable, always smile, understand students' characteristics and does not teach in monotone ways. In this sense, we can see that there is relationship between students' autonomy and motivation which can be derived from the teacher's characteristics (humorous, enjoyable, and smiling face).

Based on Findings 2, related to the question: And what kind of teaching strategies are 
more interesting and effective in order to create more enjoyable English language learning? then, it is revealed that the students prefer the teacher who has more various teaching strategies (students-centered learning, doing some games, and discussion).

\section{CONCLUSION}

Based on the two Findings, it can be concluded that to improve the students' motivation in English language learning of EFL classroom, then, the teacher has to be more enjoyable, has good sense of humor, understand the students' characteristics and has to be able to conduct more students-centered learning, games, and discussion. By doing so, the English language learning can be more enjoyable and effective.

\section{ACKNOWLEDGMENTS}

We thank the family who have given us support both morally and materially, so that we can complete and publish our article.

\section{REFERENCES}

Gardner, R. C. (1988). The Socio-Educational Model Of Second-Language Learning: Assumptions, Findings, And Issues. Language Learning, 38(1), 101-126.

Gardner, R. C. (2007). Motivation And Second Language Acquisition.

Gardner, R. C. (2010). Motivation And Second Language Acquisition: The Socio-Educational Model (Vol. 10). Peter Lang.

Gehart, D. R., Ratliff, D. A., \& Lyle, R. R. (2001). Qualitative Research In Family Therapy: A Substantive And Methodological Review. Journal Of Marital And Family Therapy, 27(2), 261-274.

Parmawati, A. (2018). The Study Correlation Between Reading Habit And Pronunciation Ability At The Second Grade Students Of Ikip Siliwangi. Eltin Journal, Journal Of English Language Teaching In Indonesia, 6(1), 46-52.

Slattery, M., \& Willis, J. (2001). English For Primary Teachers: A Handbook Of Activities And Classroom Language (Vol. 1). Oxford University Press.

Syarifuddin, S. (2017). Improving Of Efl Learners'speaking Proficiency Through Speaking Activities Inside And Outside The Classroom: A Theoretical Review. Let: Linguistics, Literature And English Teaching Journal, 2(2), 73-83.

Tanveer, M. (2007). Investigation of the factors that cause language anxiety for ESL/EFL learners in learning speaking skills and the influence it casts on communication in the target language. University of Glasgow, Scotland. 